\title{
Effect of Acetic Acid Ester and KUMGANG Medicine Stone in Silkworm Rearing with Artificial Diet and Mulberry
}

\author{
Kim MyongGuk, Cha JinMyong, Kim JongGill, Son YuHyok, Kim Chan Ryong, Kim MyongRak, Ri SongGu
}

Kyeungsang Sariwon University of Agriculture, Pyongyang, 950003, Democratic People's Republic of Korea

\author{
Article Info \\ Volume 8 Issue 1 \\ Page Number: 01-11 \\ Publication Issue : \\ January-February-2021
}

\section{Article History}

Accepted : 01 Jan 2021

Published : 10 Jan 2021

\section{ABSTRACT}

Raising silkworms by using artificial feed is not affected by the seasons and can realize the industrialization of silkworm breeding. The study has been conducted the research for using acetic acid as the material of organic acid in fresh mulberry and KUMGANG medicine stone in which various mineral salts are many contained as the material of inorganic salts in artificial feed. When acetic acid esterfied is added to artificial diet as rate of $3.3 \%$, the setae dispersion within $48 \mathrm{~h}$ was above $98 \%$ and the incentive was $100 \%$. Antiseptic effect on artificial feed has been maintained for $90 \mathrm{~h}$ since falling the feed. Acetic acid has raised the feeding habit on the 3rd instar larvae as the rate of $118.5 \%$ to $128.4 \%$ and the body weight as the rate of $104.5 \%$. KUMGANG medicine stone of the rate of $1 \%$ on artificial feed has promoted the growth and development of young silkworm. In the autumn with bad condition on rearing, KUMGANG medicine stone has been decreased the disease occurrence in larvae and raised the quality and yield of cocoon.

Keywords : Bombyx Mori L, Artificial feed Rearing, Organic acid, KUMGANG medicine stone.

\section{INTRODUCTION}

Raising silkworms using artificial feed can promote the growth of silkworms while not being affected by the seasons and realize the industrialization of silkworm breeding. Recently, there has been an active research project to raise silkworms by using artificial feed. There is also active research on the effects of organic acids on the growth and sanitary conditions of mulberry silkworms. Using a comparative protein approach, the effects of different diets on the growth and development of cultured silkworms at the protein level were analyzed [1].PSG revealed posterior silk gland as the most important factor responsible for synthesis and secretion of silk-mediated fibrin protein in silkworms, and analyzed several factors secreted by
PSG [2].Carried on the comparison with the method of rearing with artificial diet method and rearing silkworm in bulk, analyzed the factors to artificial diet [3].A proteome study was conducted to characterize the protein profile of silkworm chrysalis and how to optimize the breeding strategy [4].The specific comparison of the contents of amino acids, carbohydrates and lipids in the feces of mulberry leafbred silkworm and artificial forage was made, raising a new improvement method for artificial forage [5].The factors affecting the feeding time of silkworm larvae, Bombyx mori, were investigated, and continuous observation showed that feeding was at regular intervals throughout the outbreak [6]. In vivo uptake of titanium dioxide ( $\mathrm{TiO} 2$ ) nanoparticles by silkworms was studied to induce the direct production of modified silk [7]. The performance of

Copyright : (C) the author(s), publisher and licensee Technoscience Academy. This is an open-access article distributed under the terms of the Creative Commons Attribution Non-Commercial License, which permits unrestricted noncommercial use, distribution, and reproduction in any medium, provided the original work is properly cited 
bivoltine Bombyx mori larvae cultured from different host plant varieties was specifically analyzed according to different contents [8]. The feedstock efficacy of silkworm Bombyx mori for $\mathrm{V}$ instar larvae fed by kanva-2 mulberry leaves with Riboflavin (Morus alba) and b-complex vitamins treated with Riboflavin (0.5\%), Pantothenic acid (0.5\%), Pyridoxal phosphate $(0.5 \%)$ and Biotin (0.5\%), Growth and economic variables were specifically studied [9].In this paper, based on the specific research analysis of the prior literatures, the effects of organic acids on the growth and sanitary conditions of mulberry silkworms were studied on how to esterify one of the organic acids in raw mulberry leaves and put it into artificial feeding. In addition, a young silkworm with a high requirement for inorganic salts, rich in mineral ingredients, has been used as the main inorganic source of artificial feeding.

\section{MATERIALS AND METHODS}

\subsection{Materials}

The composition of artificial feed was $40 \mathrm{~g}$ of Mulberry Leaf powder, 33g of soy bean care, $5 \mathrm{~g}$ of Maize powder into $\alpha$-state, $5 \mathrm{~g}$ of sugar, $5 \mathrm{~g}$ of yeast, $5 \mathrm{~g}$ of citric acid, $2 \mathrm{~g}$ of Vitamin C, $5 \mathrm{~g}$ of agar, $230 \mathrm{ml}$ of $\mathrm{H} 2 \mathrm{O}$ and $30 \mathrm{ml}$ of antiseptic liquid.

The acetic acid ester is the primary liquid that glacial acetic acid, alcohol and sulfuric acid of the density with $90 \%$ are blended to composition of $4: 4: 1$ and used as antiseptic liquid diluted to $11 \%$.

KUMGANG medicine stone (YONSAN county, north of HWANGHA province.) is plain grey powder with 100 mesh of the particle size and the Mulberry silkworm variety was No.201 and 401 as normal one.

\subsection{Methods}

(1) Acetic acid ethylester by ratio of $11 \%$ as antiseptic liquid was put to amounts of $10 \mathrm{ml}(1.1 \%), 20 \mathrm{ml}(2.2 \%)$, $30 \mathrm{ml}(3.3 \%)$ per $100 \mathrm{~g}$ of dry weight in artificial feed. In test were measured the incentive ratio which the 1 arvae has dispersed for artificial diet after hatching, th e setae dispersion within $48 \mathrm{~h}$, the eating habit and the body weight of the 3rd instar larvae.
Then, the antiseptic effect of acetic acid ethylester wa $\mathrm{s}$ investigated in contrasting occurrence quantity of $A$ spergillus oryzae and Asp. flabus on artificial diet wit $\mathrm{h}$ the contrast plot for 4 days. In contrast test, propioni $\mathrm{c}$ acid as antiseptic acid was put in rotio of $1.5 \%$.

Eighther acetic acid ester of various densities was feed ed on the $5^{\text {th }}$ instar larva in autumn which mulbery le ave has stiff and bad, then the effect of it on survivalit $y$ of larava and cocoon quality was aasaied.

(2)KUMGANG medicine stone was added to artificial feed as amount of $1 \%$ and $3 \%$. The setae dispersion within $48 \mathrm{~h}$ from hatching time, the period of every instar larvae, the growth coefficient(contrasting with mulberry silkworm growth indicated as 1.0) and the every instar molted ratio, etc. were investigated.

Test for use of KUMGANG medicine stone has done i $\mathrm{n}$ autumn with bad rearing condition.

For the purpose of disinfection and staining of silk worm egg surface, we got ready for the turbid liquid which KUMGANG stone powder was solved as quantity of 3\% in alcohol by $70 \%$, and then a day ago silkworm egg hatch, it was put in the liquid for 3 minutes.

After hatching, the liquid was diluted as 3 times and fed to young lavae by one time a day with mulberry.

The survey indexes were arranged as the period and $t$ he molted ratio of every instar, the survivality of old $\mathrm{s}$ ilkworm, the yield and the quality of cocoon.

\section{RESULTS}

\subsection{Effect of acetic acid ester to the growth of larva,} the anticeptic property and the cocoon quality on silkworm rearing with artificial diet and mulberry.

1) Effect of acetic acid ethylester to the growth, the eating habit of silkworm and the antiseptic property on artificial feed. 
Acetic acid ethylester has shown the incentive, and young silkworm larvae better and shown some made the setae dispersion ratio and the growth of antiseptic effect against artificial feed. (Table1)

Table1.The added density of acetic acid ethylester to the growth of silkworm and antiseptic effect against artificial feed.

\begin{tabular}{|l|c|c|c|}
\hline Index & $\begin{array}{c}\text { Incentive } \\
\%\end{array}$ & $\begin{array}{c}\text { Setae dispersion } \\
\text { ratio } \%\end{array}$ & $\begin{array}{c}\text { Nolted ratio/ } \\
\text { slept ratio \% }\end{array}$ \\
\hline Cost plot & 100 & 95 & $92 / 94$ \\
Acetic acid ester & 0 & & \\
$0 \%$ & 95 & 88 & $68 / 75$ \\
$0.55 \%$ & 96 & 92 & $83 / 83$ \\
$1.1 \%$ & 100 & 98 & $90 / 93$ \\
$2.2 \%$ & 100 & 98 & $92 / 95$ \\
$3.3 \%$ & 100 & 98 & $92 / 96$ \\
$4.4 \%$ & & & $90 / 96$ \\
\hline
\end{tabular}

Contrast plot; Propionic acid adding. Variety; No 401.

Septic area; on $90 \mathrm{~h}$ after newly hatching

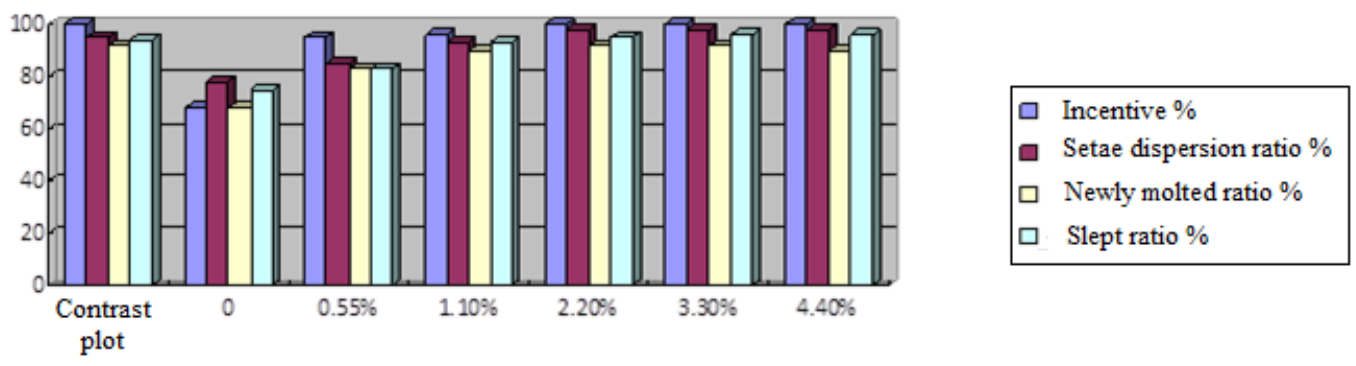

Figure1. Growth of silkworm by densities of ester against artificial feed

As shown in Table 1, the incentive are shown apparently on the rate of $2.2 \%$ and the setae dispersion ratio showed as many more than $98 \%$ on the rate of $3.3 \%$.

The slept ratio and molted ratio of 1st instar larvae was similar to the contrast plot as $95 \%$ and $92 \%$ on rate of $2.2 \%$.

The antiseptic effect of acetic acid ester appeared on the density of $0.55 \%$ and then the fungi flourishing on the artificial diet were inhibited on the density of above $3.3 \%$ for some 4 day (some $90 \mathrm{~h}$ ) since feeding on. 
Table 2.The antiseptic effect of acetic acid ethylester against artificial feed.

\begin{tabular}{|c|c|c|c|c|}
\hline \multirow{2}{*}{ Test plot } & \multirow{2}{*}{$\begin{array}{l}\text { Septic diet } \\
\text { area } \%\end{array}$} & \multicolumn{2}{|c|}{$\%$ of it } & \multirow{2}{*}{$\begin{array}{l}\text { Septic } \\
\text { degree }\end{array}$} \\
\hline & & $\begin{array}{c}\% \\
\text { Asp. Flabus }\end{array}$ & $\begin{array}{c}\% \\
\text { Asp. Oryzae }\end{array}$ & \\
\hline Contrast plot & \multirow[t]{2}{*}{0} & 0 & 0 & 0 \\
\hline Acetic acid este & & & & \\
\hline $0.55 \%$ & 100 & 60 & 40 & +++ \\
\hline $1.1 \%$ & 16 & 10 & 6 & + \\
\hline $2.2 \%$ & 10 & 2 & 8 & - \\
\hline $3.3 \%$ & 0.5 & 0 & 0.5 & $\ldots$ \\
\hline $4.4 \%$ & 0 & 0 & 0 & 0 \\
\hline & 0 & 0 & 0 & 0 \\
\hline
\end{tabular}

Contrast plot; Propionic acid adding. Septic area; on 90h after newly hatching

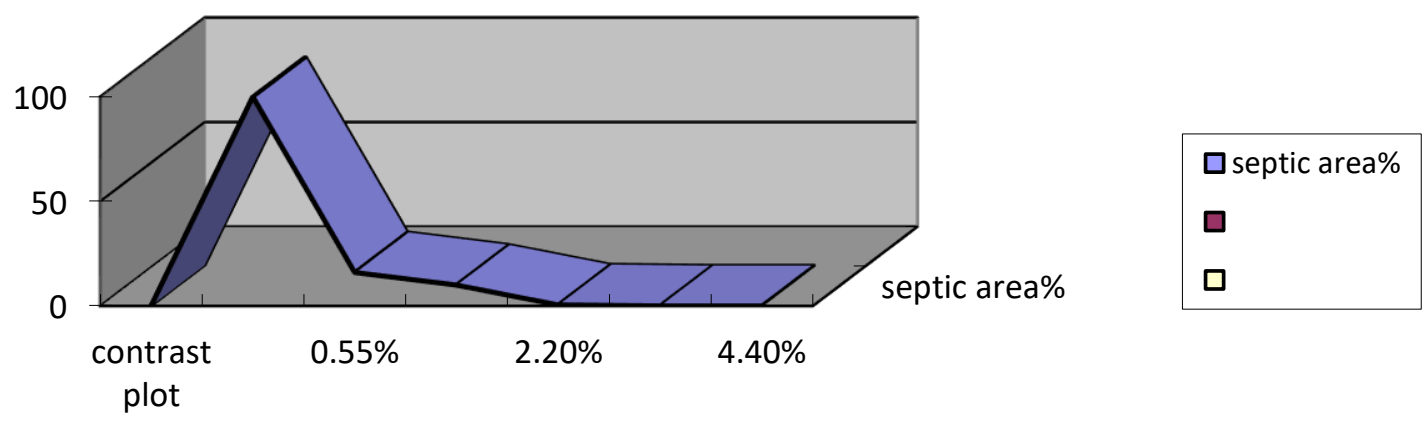

Figure 2. Antiseptic effect by densities of ester against artificial feed

The antiseptic effect of acetic acid ethylester against artificial feed inhibition action of each components for fungi. It is provided with acetic acid and alchol, secondarly supplied with sulpharic acid catalytic action for ester (Table 3). 
Table 3. The antiseptic effect of each components consisting acetic acid ester

\begin{tabular}{|c|c|c|c|c|}
\hline & \multirow{2}{*}{$\begin{array}{c}\text { Septic diet } \\
\text { area } \%\end{array}$} & \multicolumn{2}{|c|}{$\%$ of it } & Septic \\
desegree
\end{tabular}

Diet area; $40 \times 60 \mathrm{~cm}^{2}$, temperature $29^{\circ} \mathrm{C}$, humidity $85 \%$. On $72 \mathrm{~h}$ after feeding

As the shown the table, the inhibition effect for fungi is the highest for mixture acetic acid and alchol, then ethyl alchol inhibited Asp. Oryzae but not Asp. flabus.

Acetic acid ester has raised the eating habit and the growth of the $3^{\text {rd }}$ instar larva more than the mixture of acetic acid and alchol having the similar anticeptic action (Table 4).

Table 4. Effect of acetic acid ester to feeding habit and body weight of 3rd instar

\begin{tabular}{|c|c|c|c|c|c|c|c|c|c|c|}
\hline & & $2^{\text {nd }}$ day & of $3 \mathrm{rd}$ ins & & & & & day of & rd instar & \\
\hline Test plot & $\begin{array}{c}\text { Larva } \\
\text { numb- } \\
\text { er off } \\
\text { diet } \\
1\end{array}$ & $\begin{array}{c}\text { Dead } \\
\text { larva } \\
\text { Num- } \\
\text { ber } \\
2\end{array}$ & $\begin{array}{l}\text { Dropi- } \\
\text { ngs per } \\
\text { head } \\
3\end{array}$ & $\begin{array}{c}\text { Contr- } \\
\text { ast } \\
\% \\
\\
4\end{array}$ & 1 & 2 & 3 & 4 & $\begin{array}{c}\text { Body } \\
\text { weight } \\
\text { per head, }\end{array}$ & 4 \\
\hline $\begin{array}{l}\text { Acetic acid+ } \\
\text { alcohol } \\
\text { Acetic acid ester }\end{array}$ & 2 & 0 & $\begin{array}{l}10.8 \\
12.8\end{array}$ & $\begin{array}{l}100.0 \\
118.5\end{array}$ & 0 & 2 & $\begin{array}{l}23.6 \\
30.3\end{array}$ & $\begin{array}{l}100.0 \\
128.4\end{array}$ & $\begin{array}{l}116.7 \\
122.0\end{array}$ & $\begin{array}{l}100.0 \\
104.5\end{array}$ \\
\hline
\end{tabular}

Variety; No 201. N=30heads larvae body weight; mg 


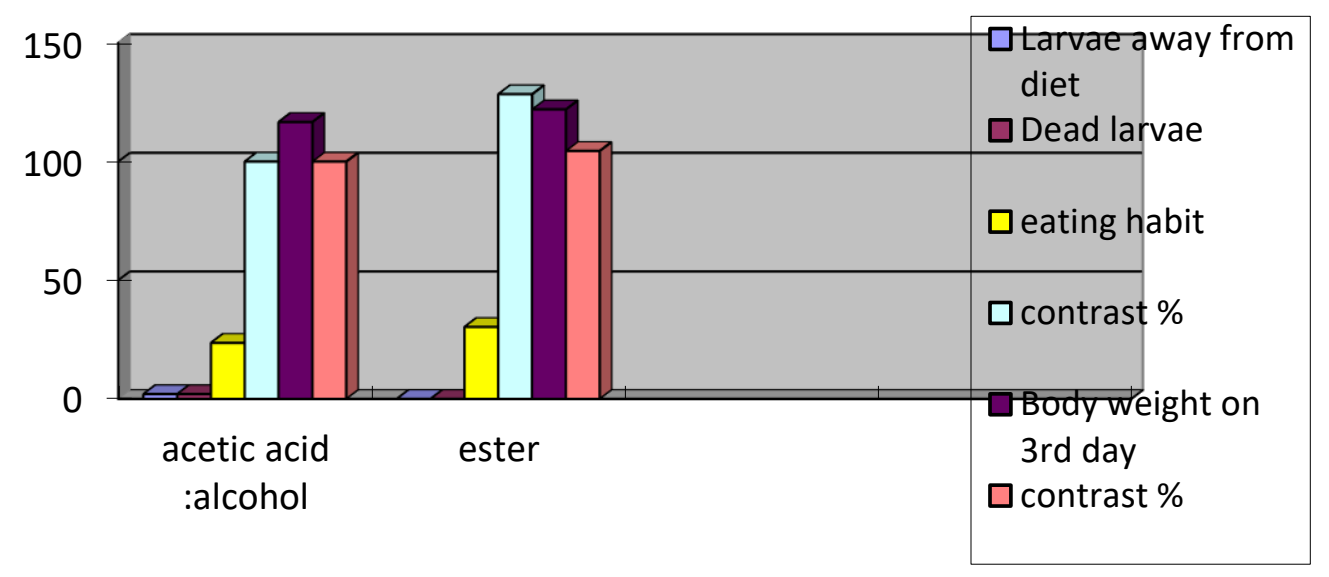

Figure 3. Eating habit and growth of silkworm on the feed esterized

As shown in the table 4, acetic acid ester has raised the feeding habit as ratio of $118.5 \%$ to $128.4 \%$, and the body weight as ratio of $104.5 \%$ many more than the mixture of acetic acid and alcohol.

This means that when acetic acid is esterized with alcohol put to artificial feed it has raised the setae dispersion and eating habit and made growth of silkworm better.

2)The effect of acetic acid ester to survivality of $5^{\text {th }}$ instar larva and cocoon quality in autumn.

When feeding acetic acid ester on 5rd instar larva in autumn having a few low quality of mulbery leaf, the larva period was shorten and the survivality and the cocoon quality was raised(Table 5).

Table 5. Effect of acetic acid ester on the period and the survivality of 5rd instar larva

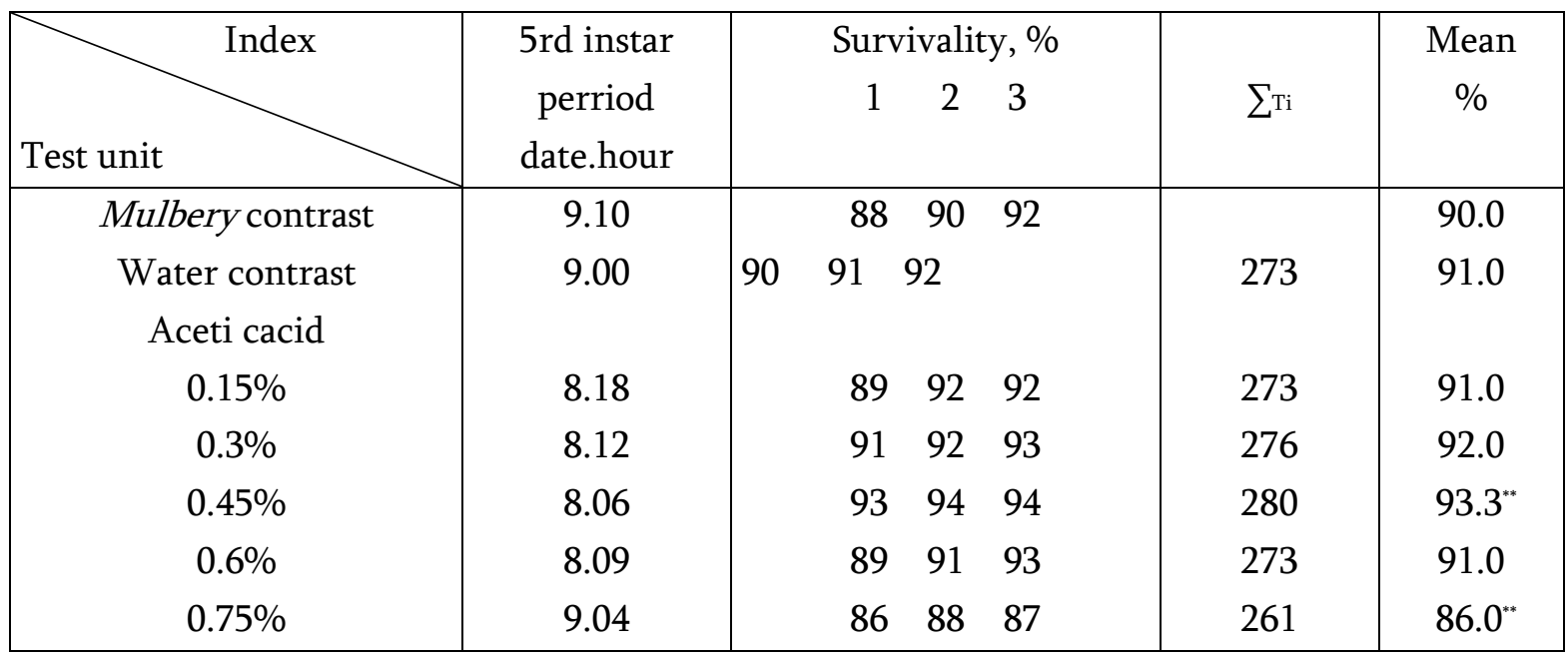

Variety; No 201. N=200×3. to.05= 2.365 < tн20,0.45\%=5.11, to.01= 3.499<

As the shown the table, acetic acid ester has the $5^{\text {th }}$ inster period more shorten as 8 hours for the rate of $0.4 \%$ th an water contrast. Then, the survivality of the $5^{\text {th }}$ instar larva was painly raised as the rate of $93.3 \%$ on feeding e ster by the rate $0.45 \%$, and it was proved on the significant level of $5 \%$ and $1 \%$ as the result of dicentralization $\mathrm{f}$ or investigation values. Also when adding an dillute solution of acetic acid ester on the $5^{\text {th }}$ instar larva, the weig ht of cocoon and cocoon shell was both raised in autumn(Table-5). 
Table 6. Effect on feeding of acetic acid ester to the $5^{\text {th }}$ instar larva for the quality of cocoon in autumn.

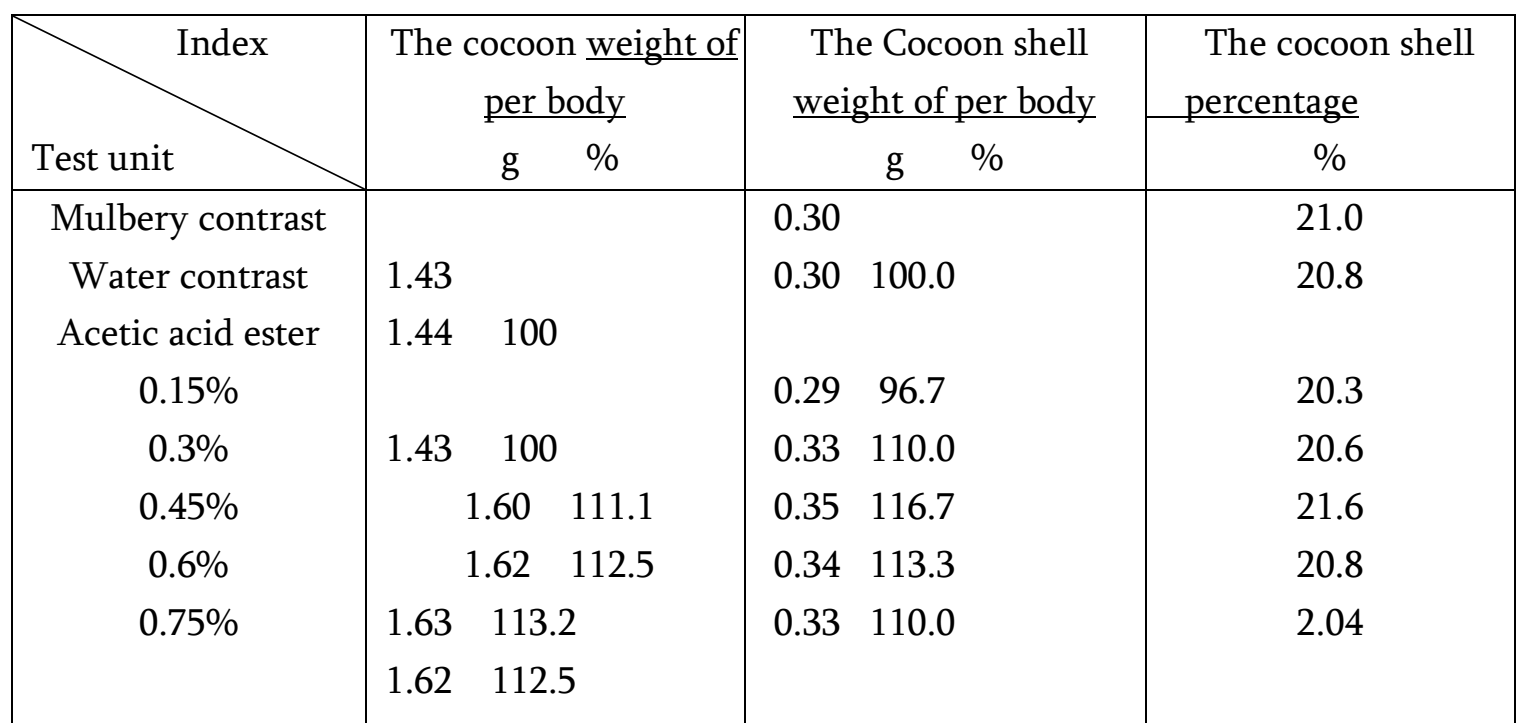

Variety; No 201. On feeding one time a day during $5^{\text {th }}$ instar.

As the table, on the ester dencity $0.6 \%$, the cocoon weight and cocoon shell weight was more higher as each 1 . $63 \mathrm{~g}$ and $0.34 \mathrm{~g}$ than $1.44 \mathrm{~g}$ and $0.3 \mathrm{~g}$ of water contrast. When feeding acetic acid ester of the rate of $0.45 \%$ to the $5^{\text {th }}$ instar larva in autumn, the survivality of larva has been raised more $2^{\sim} 3 \%$, cocoon shell weight more 116.7 $\%$ than ones, of water contrast.

Thus, when feeding acetic acid ester of a low density with mulbery of a few organic acid in autumn, the surviva lity of larva and cocoon quality were both higher.

\subsection{The effect of KUMGANG medicine stone on silkworm rearing by artificial diet and Mulberry.}

1) The effect of KUMKANG medicine stone to growth and development of young silkworm by artificial feed. KUMGANG medicine stone as inorganic salts of artificial feed has raise set-ae dispersion ratio and made the gro wth of newly hatched larvae better.

When adding KNMGANG medicine stone to artificial feed by ratio of $1 \%$ and $3 \%$, the setae dispersion ratio on $48 \mathrm{~h}$ after feeding was more higher as $93 \%$ and $95 \%$ than $90 \%$ of contrast plot. (Table 7)

Table 7. The Effect of KUMGANG medicine stone to young silkworm rearing by artificial feed

\begin{tabular}{|c|c|c|c|c|c|c|c|c|c|c|}
\hline \multirow[b]{2}{*}{ Test plot } & \multirow{2}{*}{$\begin{array}{r}\text { Head } \\
\text { number }\end{array}$} & \multicolumn{3}{|c|}{$1^{\text {st }}$ instar } & \multicolumn{3}{|c|}{$2^{\text {nd }}$ instar } & \multicolumn{3}{|c|}{$3^{\text {rd }}$ instar } \\
\hline & & $\begin{array}{l}\text { Setae } \\
\text { dispersion } \\
\text { ratio, } \%\end{array}$ & $\begin{array}{l}\text { Body } \\
\text { size }\end{array}$ & Period & $\begin{array}{l}\text { Molted } \\
\text { ratio,\% }\end{array}$ & $\begin{array}{l}\text { Body } \\
\text { size }\end{array}$ & Period & 1 & 2 & 3 \\
\hline Contrast plot & 1000 & 90 & 0.9 & 5.00 & 30 & 0.75 & 3.01 & 36 & 0.8 & 4.07 \\
\hline Kumgang 3\% & 1000 & 93 & 0.95 & 5.00 & 83 & 0.90 & 3.01 & 86 & 0.9 & 4.07 \\
\hline Kumgang 1\% & 1000 & 95 & 0.95 & 5.00 & 85 & 0.95 & 3.01 & 88 & 0.87 & 4.07 \\
\hline
\end{tabular}

Body size; surveying on $3^{\text {rd }}$ day of every instar.

The body size on the 3rd day in 1st instar larvae was remarkably larger as 0.95 than 0.90 of contrast plot and the tendency was further parent on the 2nd and 3rd instar larva. 
Especially, since the 2nd instar larvae, the first molting ratio of KUMGANG test plot was remarkably as larger as $85 \%$ and $83 \%$ than $30 \%$ of the contrast plot and the tendency was similar to the 3rd instar larva.

This means that in artificial feed rearing KUMGANG medicine stone gives a good effect to raise the larvas growth and development as the setae dispersion, the body size and the $2^{\text {nd }} 3^{\text {rd }}$ hatching ratio.

2) The effect to the growth and the disease occurrence of silkworm in autumn by treatment and feeding of KUMGANG medicine stone.

In autumn with bad silkworm rearing, since the 3rd instar, the period of larvae was shorted and the development equilibrium was large and the disease occurrence ratio too was low by feeding of KUMGANG medicine stone .(Table 8)

Table 8. The effect of KUMGANG medicine stone on growth and disease occurrence of silkworm in autumn rearing

\begin{tabular}{|c|c|c|c|c|c|c|c|c|c|}
\hline \multirow[b]{2}{*}{$\begin{array}{c}\text { The test } \\
\text { plot }\end{array}$} & \multirow[b]{2}{*}{$\begin{array}{l}\text { Moth } \\
\text { number }\end{array}$} & \multicolumn{2}{|c|}{$3^{\text {rd }}$ instar } & \multicolumn{3}{|c|}{$4^{\text {th }}$ instar } & \multicolumn{3}{|c|}{$5^{\text {th }}$ instar } \\
\hline & & Period & $\begin{array}{c}\text { Molted } \\
\text { ratio } \\
\%\end{array}$ & $\begin{array}{c}1 \text { stday disease } \\
\text { occurrence } \\
\%\end{array}$ & $\begin{array}{c}4^{\text {th }} \text { day disease } \\
\text { occurrence } \\
\%\end{array}$ & Period & $\begin{array}{c}\text { Disease } \\
\text { occurrence } \\
\%\end{array}$ & $\begin{array}{c}\text { Survival } \\
\text { ty } \\
\%\end{array}$ & Period \\
\hline & 5 & 4.15 & 30 & 7 & 90.0 & 7.06 & 15.0 & 25.3 & 8.00 \\
\hline 0 & 5 & 4.15 & 50 & 10 & 60.0 & 6.00 & 5.0 & 45.7 & 8.00 \\
\hline KUMGA-NG & 5 & 4.03 & 90 & 0 & 5.0 & 5.0 & 2.0 & 93.1 & 8.00 \\
\hline
\end{tabular}

*The period of $1^{\text {st }} 2^{\text {nd }}$ instar; 8days and 20hours.

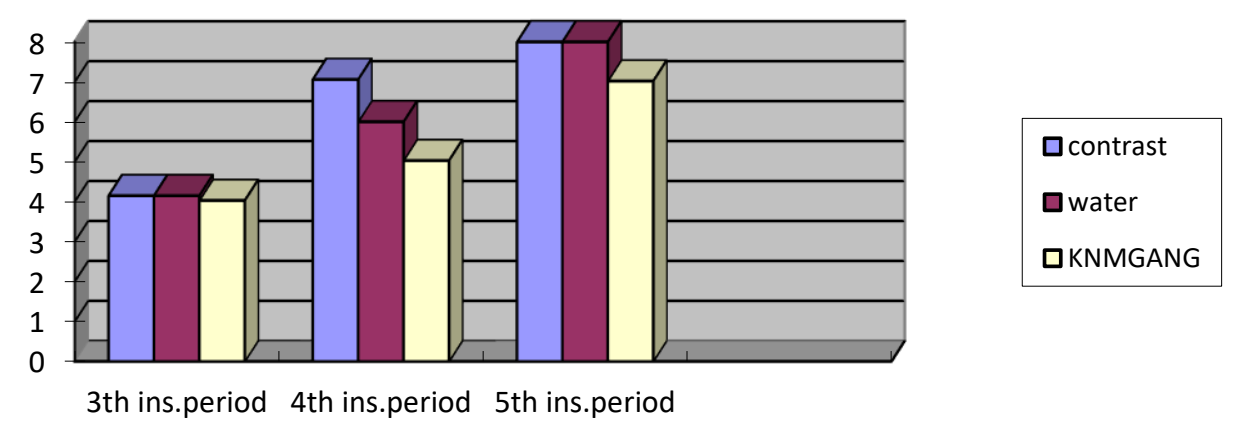

Figure 4. Adding of KUMGANGE medicine stone and period of the $3 \sim 5$ instar larvae 


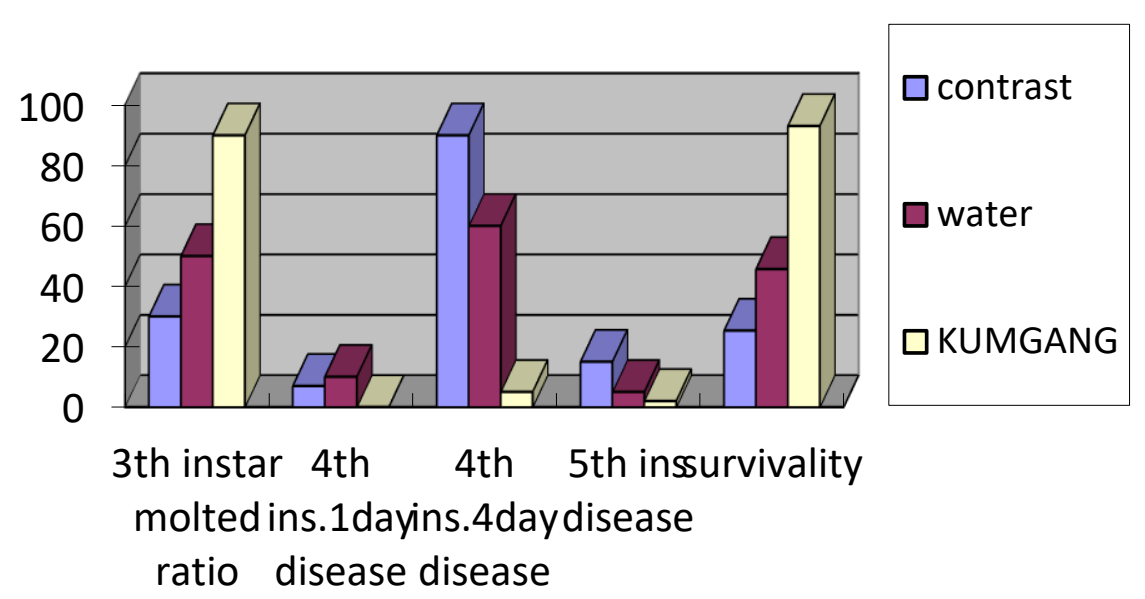

Figure 5. Adding of KUMGANG medicine stone and the 3rd instar molted ratio, disease occurrence in 4 5th instar larvae and survival ratio.

As shown in the table 8, in KUMGANG medicine stone test, there were none disease silkworms in 4th instar, but in the contrast plots of water and mulberry the disease silkworms have been occurring with $10 \%$ and $7 \%$ on first day of the 4th instar and there were suddenly many disease silkworms occurred with the ratio of $60 \%$ and $90 \%$ for the 4 th instar.

The tendency either appeared in too 5th instar period, which the disease occurrence ratio of KUMGANG stone test plot was some of $2 \%$ but in contrast plots of mulberry and water were as many as $15 \%$ and $5 \%$.

The 4th instar period has been shorted as 1 to 2 days and the 5th instar period shorted as one day than the contrast plots.

3) The effect of treatment and feeding by KUMGANG medicine stone on the yield and quality of cocoon.

In autumn silkworm rearing, the treatment on silkworm egg surface before hatching and the feeding to young silkworm with KUMGANG medicine stone solution have raised the yield and quality of cocoon. (Table 9)

As shown table 9, in KNMGANG medicine stone plot the disease occurrence ratio in period making cocoon was very lower as $6.9 \%$ than $74.7 \%$ or $54.3 \%$ of Mulberry plot or water plot, and the cocoon yield ratio was more larger as some two times as $93.1 \%$ than $45.7 \%$ of water plot.

In the cocoon quality of KUMGANG plot, the average weigh per head of female and male on cocoon and cocoon shell as apart of $1.85 \mathrm{~g}$ and $0.36 \mathrm{~g}$ were some larger as ratio of $107.5 \%$ and $112.5 \%$ than $1,72 \mathrm{~g}$ and $0.32 \mathrm{~g}$ of water plot, and the cocoon shell ratio too were rather larger as $19.5 \%$ than $18.9 \%$ of mulberry plot.

Table 9. The effect of KUMGANG medicine stone on the yield and quality of cocoon

\begin{tabular}{|c|c|c|c|c|c|c|c|c|}
\hline \multirow[b]{2}{*}{ Test plot } & \multirow{2}{*}{$\begin{array}{c}\text { Cocoon } \\
\text { harvest } \\
\text { ratio } \\
\%\end{array}$} & \multirow[b]{2}{*}{ Contrast } & \multirow{2}{*}{$\begin{array}{c}\text { Disease } \\
\text { cocoon } \\
\text { Ratio }\end{array}$} & \multicolumn{2}{|c|}{ Per cocoon } & \multicolumn{2}{|c|}{ Per cocoon shell } & \multirow{2}{*}{$\begin{array}{l}\text { Cocoon } \\
\text { shell } \\
\text { ratio } \\
\%\end{array}$} \\
\hline & & & & $\begin{array}{c}\text { Weight } \\
\text { g }\end{array}$ & $\begin{array}{c}\text { Contrast } \\
\%\end{array}$ & $\begin{array}{c}\text { Weight } \\
\text { g }\end{array}$ & $\begin{array}{c}\text { Contrast } \\
\%\end{array}$ & \\
\hline $\begin{array}{c}\text { Contrast } \\
\text { plot }\end{array}$ & 25.3 & 0.55 & 74.7 & 1.75 & 101.7 & 0.33 & 103.1 & 18.9 \\
\hline $\begin{array}{c}\text { Water } \\
\text { KNMGAN- }\end{array}$ & 45.7 & 1.00 & 54.3 & 1.72 & 100.0 & 0.32 & 100.0 & 18.6 \\
\hline G & 93.1 & 2.04 & 6.90 & 1.85 & 107.6 & 0.36 & 112.5 & 19.5 \\
\hline
\end{tabular}

${ }^{*}$ Contrast number and \% were counted with water plot as normal. 


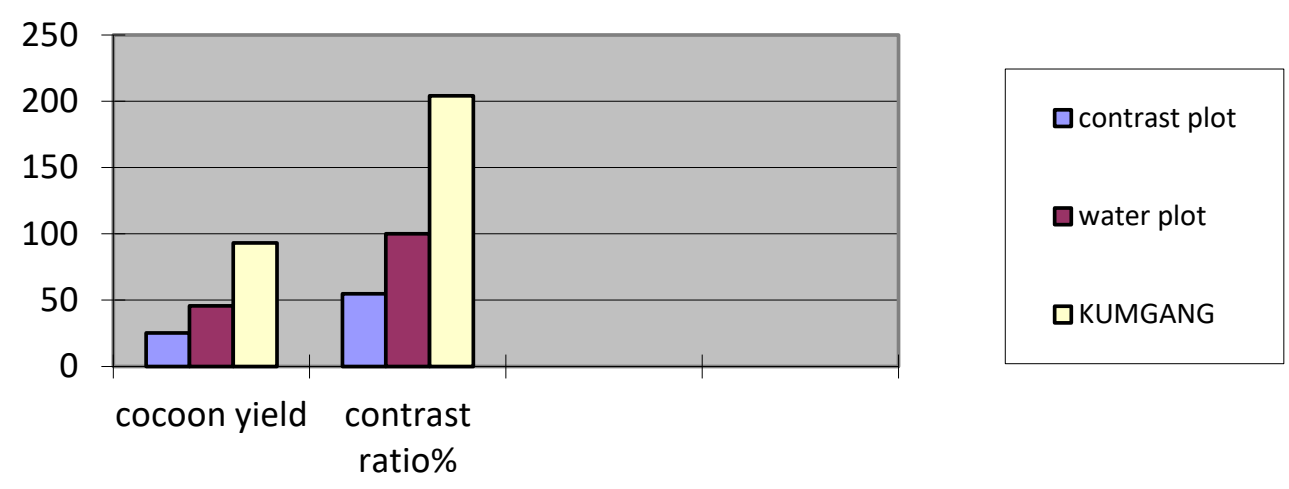

Figure 6. Yield of cocoon by adding of KUMGANG medicine stone

As thus, when feeding to young silkworm KUMGANG medicine stone as the nutrient source of inorganic salts, the silkworm growth has been promoted and the disease occurrence ratio was low, and the cocoon yield and quality both were improved. Thereby, when advancing the utilization method of KUMGANG medicine stone, we relive the effect will be large more than.

\section{DISCUSSION}

Acetic acid ester raised the incentive and the setae dispersion of young silk worm and promoted the eating habit and growth of the $3^{\text {rd }}$ instar larvae in artificial feed rearing, it is because of that the action of organic acids including acetic acid in fresh mulbery was raised. The property of acetic acid ester has appeared to raised the survivality of larva and the cocoon quality in autumn which the quality of mulbery leave falls to low, it is shown. Also, it inhibited the occurrence of fungi flourishing on artificial diet as similar to the contrast plot added propionic acid. It is shown that the definite antiseptic action of acetic acid ester is by the mixture of acetic acid and alchol. When using KUMGANG medicine stone as the inorganic salts material, it can raised the setae dispersion and every instar molted ratio and promoted the growth of larvae. Either, before and after of hatching in autumn rearing when feeding KUMGANG medicine stone to mulberry silk worm larvae, it can raise the survivality of larvae and improve the yield and quality of cocoon.

\section{CONCLUSION}

Based on the effect of organic acid on mulberry silkworm growth and sanitary condition of silkworm rearing, it was studied how to add to artificial diet by esterifying acetic acid as one of organic acid in fresh mulberry. Acetic acid ethylester has promoted the silkworm growth including the setae dispersion ratio when put as amounts of $30 \mathrm{ml}$ by Acetic acid ester $11 \%$ per $100 \mathrm{~g}$ of dry weight in artificial diet. Then, it's antiseptic effect is maintained for $90 \mathrm{hs}$ after giving artificial feed. The feeding habit of the 3rd instar larva was large as $118.5^{\sim} 128.4 \%$ and the body weight was large as $104.5 \%$ with acetic acid ester. When feeding acetic acid ester of the rate of $0.45 \%$ to the $5^{\text {th }}$ instar larva in autumn, the survivality of larva has been raised more 2 3\%, cocoon weight per body more $113.2 \%$ and cocoon shell weight more $116.7 \%$ than ones of water contrast unit. KUMGANG medicine stone has promoted the silkworm growth and raised the molted ratio of silkworm in rearing with artificial feed remarkably. Before hatching the treatment of egg and the feeding to larva by KUMGANG medicine stone alcohol liquid have elevated the 3rd instar molted ratio and make the period of 4 th to 5 th instar larva shorted as $1^{\sim}$ 2days and have the occurrence ratio to very lower range in autumn silk worm rearing. 
Either, the treatment and feeding by KUMGANG medicine stone in dilute alcohol solution have raised the cocoon yield as twice, the cocoon weight per head $107.6 \%$ and the cocoon shell weight as $112.5 \%$.

\section{REFERENCES}

[1]. Zhong-hua Zhou, Hui-juan Yang, Ming Chen. Comparative Proteomic Analysis between the Domesticated Silkworm (Bombyx mori) Reared on Fresh Mulberry Leaves and on Artificial Diet, Journal of Proteome Research, 2008, 7: 5103-5111.

[2]. JianYing Li, HuiJuan Yang, TianYun Lan. Expression Profiling and Regulation of Genes Related to Silkworm Posterior Silk Gland Development and Fibroin Synthesis, Journal of Proteome Research 2011, 10 (8): 35513564

[3]. Luciano C, Silvia C. Artificial diet rearing system for the silkworm Bombyx mori (Lepidoptera: Bombycidae): effect of vitamin $C$ deprivation on larval growth and cocoon production, Appl. Entomol. Zool, 2005, 40 (3): 405-412.

[4]. Cristina L, Francesco G.Investigation of the protein profile of silkworm (Bombyx mori) pupae reared on a well-calibrated artificial diet compared to mulberry leaf diet, ZOOLOGICAL SCIENCE, 2019, 31223520.

[5]. DaoYuan Qin, GenHong Wang. Comparative Fecal Metabolomes of Silkworms Being Fed Mulberry Leaf and Artificial Diet, Insects, 2020, 11(12):851.

[6]. Shinji Nagata, Hiromichi Nagasawa. Effects of diet-deprivation and physical stimulation on the feeding behaviour of the larvae of the silkworm, Bombyx mori, Journal of Insect Physiology, 2006, 52(8): 807-815.

[7]. Lingyue Cai, Huili Shao, Xuechao Hu. Reinforced and Ultraviolet Resistant Silks from Silkworms Fed with Titanium Dioxide
Nanoparticles, ACS Sustainable Chem. Eng. 2015, 3(10): 2551-2557.

[8]. Lalfelpuii Ruth, Souvik Ghatak. Influence of Micronutrients on the Food Consumption Rate and Silk Production of Bombyx mori (Lepidoptera: Bombycidae) Reared on Mulberry Plants Grown in a Mountainous Agro-Ecological Condition, Frontiers in Physiology, 2019, 10: 878.

[9]. Kunal Sarkar. STUDIES ON THE FEED EFFICACY, GROWTH RATE AND ECONOMIC TRAITS OF Silkworm Bombyx mori (L.) (LEPIDOPTERA: BOMBYCIDAE) FED WITH RIBOFLAVIN TREATED KANVA-2 MULBERRY LEAVES, International Journal of Agriculture, Environment and Biotechnology, 2017, 5(1): 1460-1467

\section{Cite this article as :}

Kim MyongGuk, Cha JinMyong, Kim JongGill, Son YuHyok, Kim Chan Ryong, Kim MyongRak?Ri SongGu, "Effect of Acetic Acid Ester and KUMGANG Medicine Stone in Silkworm Rearing with Artificial Diet and Mulberry", International Journal of Scientific Research in Science, Engineering and Technology (IJSRSET), Online ISSN : 2394-4099, Print ISSN : 2395-1990, Volume 8 Issue 1, pp. 01-11, January-February 2021. Available at doi : https://doi.org/10.32628/IJSRSET207648 Journal URL : http://ijsrset.com/IJSRSET207648 